\title{
Utilization of Lime Derived From Mussel Freshwater Shells (Pilsbryoconcha exilis) to Increase Swamp Water pH For Catfish (Pangasius sp.) culture
}

\author{
Dade Jubaedah ${ }^{1, *}$, Marsi $^{2}$, Marini Wijayanti ${ }^{1}$, Fifi Jayanti Putri ${ }^{1}$ \\ ${ }^{1}$ Study Program of Aquaculture, Agriculture Faculty, Universitas Sriwijaya \\ ${ }^{2}$ Study Program of Soil Science, Agriculture Faculty, Universitas Sriwijaya \\ *Corresponding Author: dadejubaedah@fp.unsri.c.id
}

\begin{tabular}{llll} 
Article history & & \\
\hline Received & Received in revised form & Accepted & Available online \\
12 October 2018 & 1 August 2019 & 30 August 2019 & 31 August 2019 \\
\hline
\end{tabular}

\begin{abstract}
The water pH of swamp land is generally low (below 4) and becomes a constraint in catfish culture that requires $\mathrm{pH}$ 6.5-8.5. In this current study, the low $\mathrm{pH}$ value of water was overcome by liming using lime produced from the mussel freshwater shells. The purposes of this study were to determine the best dosage of lime derived from mussel freshwater shells to increase the $\mathrm{pH}$ of swamp water, as well as its effect on the survival rate and growth of catfish fingerlings. This study used Completely Randomized Design (CRD) with 5 treatments and 3 replications. The treatments used were the different dosages of lime derived from mussel freshwater shells $(\mathrm{P} 1=4,000, \mathrm{P} 2=5,000, \mathrm{P} 3=6,000, \mathrm{P} 4=7,000 \mathrm{~kg} / \mathrm{ha}$ equivalent $\mathrm{CaO})$ and calcite $\left(\mathrm{CaCO}_{3}\right)$ as control $(\mathrm{P} 5=6,000 \mathrm{~kg} / \mathrm{ha}$ equivalent $\mathrm{CaO}$ ). The result showed that $\mathrm{P} 4$ was the best treatment according to data of swamp water $\mathrm{pH}$ increased from 3.4 to 8.23 , soil $\mathrm{pH}$ increased from 3.4 to 8.22 , survival rate (100\%), absolute growth of weight (56.59 g) and length $(13.37 \mathrm{~cm})$

Keywords: lime, mussel freshwater shells, pH, soil, water,
\end{abstract}

\begin{abstract}
Abstrak (Indonesian): Lahan rawa lebak umumnya memiliki $\mathrm{pH}$ air rendah (di bawah 4). Faktor inilah yang menjadi kendala dalam budidaya ikan patin yang membutuhkan $\mathrm{pH}$ 6,5-8,5. Upaya dalam mengatasi rendahnya nilai $\mathrm{pH}$ yaitu dengan dilakukan proses pengapuran menggunakan bahan alternatif berupa cangkang kijing. Tujuan penelitian ini adalah mengetahui dosis terbaik kapur yang berasal dari cangkang kijing untuk meningkatkan $\mathrm{pH}$ air rawa, pengaruhnya terhadap kelangsungan hidup dan pertumbuhan benih ikan patin. Penelitian ini menggunakan Rancangan Acak Lengkap (RAL) dengan 5 perlakuan dan 3 ulangan. Perlakuan yang digunakan yaitu perbedaan dosis kapur cangkang kijing $(\mathrm{P} 1=4.000, \mathrm{P} 2=5.000, \mathrm{P} 3=6.000, \mathrm{P} 4=7.000) \mathrm{kg} / \mathrm{ha}$ setara $\mathrm{CaO}$ dan kalsit $\left(\mathrm{CaCO}_{3}\right)$ sebagai kontrol $(\mathrm{P} 5=6.000) \mathrm{kg} / \mathrm{ha}$ setara $\mathrm{CaO}$. Hasil penelitian menunjukkan $\mathrm{P} 4$ merupakan perlakuan terbaik yang mampu meningkatkan $\mathrm{pH}$ air rawa dari 3,4 menjadi 8,23; $\mathrm{pH}$ tanah dari 3,4 menjadi 8,22 dan menghasilkan kelangsungan hidup $100 \%$, pertumbuhan bobot mutlak $56,59 \mathrm{~g}$, dan pertumbuhan panjang mutlak $13,37 \mathrm{~cm}$.

Kata kunci: kapur, cangkang kijing, pH, tanah, air
\end{abstract}

\section{Introduction}

Soil's and water's pH value in swamp area becames a basic problem for aquaculture development in this area. Problem with acid-base relationship in ponds ussually can be solved by liming. The liming materials most frequently used is agricultural limestone i.q. calcite $\left(\mathrm{CaCO}_{3}\right)$, dolomite $\left(\mathrm{CaMg}\left(\mathrm{CO}_{3}\right)_{2}\right.$ or some blend of these two substances.The others are calcium hydroxide $\left(\mathrm{Ca}(\mathrm{OH})_{2}\right)$ and calcium oxide $(\mathrm{CaO})$ [1]. Liming materials derived from domestic waste and byproduct are used as an alternative of those kind materials. The waste ashes comes from food scarp, animal waste, horticulture sewage and incinerator bottom from various locations in Japan can be used as liming agents on acid soil [2].

Based on some reseach proven that shells of Anadara granosa [3] and Pomacea canaliculata [4] have increased the soil's and water $\mathrm{pH}$ of catfish ponds and another potential shells is mussel freshwater shells (Pilsbryoconcha exilis). Mussel freshwater shell size $<90 \mathrm{~mm}$ and $>90 \mathrm{~mm}$ have calcium contain $39.55 \%$ and $28.97 \%$, respectively. Pyrolysed mussel shells are viable alternative raw material source for producing lime calcium oxide $(\mathrm{CaO})$ [5]. Based on initial research, mussel frehwater shells contain $\mathrm{CaO} 60.33 \%$ and $\mathrm{MgO}$ $19.82 \%$ Therefore, these shells potentially used as lime materials for increase soil's and water's $\mathrm{pH}$ value.

\section{Experimental Section}

\subsection{Materials}

Materials that used in this research were mussel freshwater shells, calcite, catfish, soils and water's swamp. The instruments were fish ponds $(1 \mathrm{x}$ $1 \times 1 \mathrm{~m}^{3}$ ), sieve $60,42.5$ and 30 mesh, furnace, and water quality instruments. The water $\mathrm{pH}$ was 
measured by using a portable $\mathrm{pH}$ meter. The water temperature was observed by using a digital handy thermometer. The analytical determinations of total alkalinity and total ammonia were carried out according to the guidelines presented by APHA [6]. Total ammonia was analyzed by using spectrofotometer, and alkalinity was analysed by using titration equipments.

\subsection{Methods}

\subsubsection{Sample collection and preparation}

For preparing of lime, mussel shell was colected from Belitang, Ogan Komering Ulu, South Sumatera Indonesia. The sample were washed and air-dried, then activated by burned using furnace at temperature $800^{\circ} \mathrm{C}$ for one hours and sieved. Swamp soils was air-dried and sieved using 10 mesh of sieve and placed on each pond with $15 \mathrm{~cm}$ height. Lime was spread and stirred homogeniously on soil, then incubated for 7 days at field capacity soil moisture. Soil's pH was measured daily at these times. Swamps water was filled to the ponds with $500 \mathrm{~L}$ volume for each ponds and equilibrated for 3 days. Waters's $\mathrm{pH}$ was measured daily at these times.

\subsubsection{Fish Culture}

Fish that was acclimated for one week, stocked to the ponds at 10 days after liming. The fish fed to satiation three times per day with artificial diet containing $30 \%$ protein. The water quality variables e.q. dissolved oxygen, ammonia and alkalinity were measured and analized every 20 days. Meanwhile, $\mathrm{pH}$ and temperature was measured daily. Survival and growth performace was analized in the initial and final culture.

\subsubsection{Experimental variable and analytical procedurs}

Water quality, survival and growth performance variables were observed in the present work. Water quality, survival and growth performance results were statistically analyzed according to the two-way Anova to detect if there was any significant influence due to experimental treatments. When the influence was at least significant, the means were compared using Dunnett test with P5 as control for P1, P2, P3 and P4. The 5\% significance level was adopted in all statistical analysis.

\subsubsection{Data Analysis}

The fish survival rate was calculated from the initial number of fish and mortality after the experiment was completed. The absolute growth of fish were determined from the mean of initial and final weight and length of fish, respectively for absolute weight growth and length growth. Meanwhile, feed efficiency was calculated by the formula of NRC [7].

\section{Results and Discussion}

Soil's $\mathrm{pH}$ increased in the incubation time and fish culture (Table 1 and 2). Based on statistical analysis (Table 1 and 2), soil's pH in the final day of incubation and fish culture showed that dosage 4 ton/ha and 5 ton/ha lime derived from mussel shell (P1 and P2) was lower significant different than calcite 6 ton/ha. In the same dosage of lime (6 ton/ha), mussel shell lime (P3) and calcite (p5) was unsignificat difference, but higher dosage of mussel shell lime (7 ton/ha) ( $\mathrm{P} 4)$ has highest soil's $\mathrm{pH}$ and significant difference with calcite (6 ton/ha).

Table 1. Dunnett analysis result for soil's $\mathrm{pH}$ at incubation time

\begin{tabular}{ccccccccc}
\hline Treatments & \multicolumn{7}{c}{ Soil's pH at day } \\
\cline { 2 - 9 } & 0 & 1 & 2 & 3 & 4 & 5 & 6 & 7 \\
\hline P1 & $5,93^{*}$ & $6,17^{*}$ & $6,45^{\text {tn }}$ & $6,48^{*}$ & $6,65^{*}$ & $6,77^{*}$ & $6,96^{*}$ & $6,98^{*}$ \\
P2 & $6,20^{*}$ & $6,51^{\text {tn }}$ & $6,55^{\text {tn }}$ & $6,64^{*}$ & $6,77^{\text {tn }}$ & $6,92^{*}$ & $7,16^{\text {tn }}$ & $7,39^{*}$ \\
P3 & $6,26^{*}$ & $6,64^{*}$ & $6,76^{*}$ & $6,79^{\text {tn }}$ & $6,95^{*}$ & $6,98^{\text {tn }}$ & $7,33^{*}$ & $7,63^{\text {tn }}$ \\
P4 & $6,38^{\text {tn }}$ & $6,82^{*}$ & $6,86^{*}$ & $7,16^{*}$ & $7,22^{*}$ & $7,51^{*}$ & $7,56^{*}$ & $7,75^{*}$ \\
P5 & 6.38 & 6.51 & 6.52 & 6.77 & 6.81 & 7.03 & 7.07 & 7.65 \\
\hline $\mathrm{D}_{0.05}$ & 0.068 & 0.0481 & 0.0817 & 0.0644 & 0.1259 & 0.0924 & 0.0924 & 0.0518 \\
\hline
\end{tabular}

*) : significant difference with control (P5), tn : unsignificant difference with control (P5)

Table 2. Dunnett analysis result for soil's and water's pH at 0,20,40 and 60 days fish culture

\begin{tabular}{|c|c|c|c|c|c|c|c|c|}
\hline \multirow[t]{2}{*}{ Treatment } & \multicolumn{4}{|c|}{ Soil's pH at day } & \multicolumn{4}{|c|}{ Water's pH at day } \\
\hline & 0 & 20 & 40 & 60 & 0 & 20 & 40 & 60 \\
\hline $\mathrm{P}_{1}$ & $6,98 *$ & $7,16^{*}$ & $7,25^{*}$ & $7,27 *$ & $6,85^{*}$ & $7,35 *$ & $7,50 *$ & $7,51 *$ \\
\hline $\mathrm{P}_{2}$ & $7,49 *$ & $7,66^{*}$ & $7,75^{*}$ & $7,77 *$ & $7,26^{*}$ & $7,71 *$ & $7,96 *$ & $7,97 *$ \\
\hline $\mathrm{P}_{3}$ & $7,63^{\mathrm{tn}}$ & $8,02^{\text {tn }}$ & $8,03^{\text {tn }}$ & $8,04^{\text {tn }}$ & $7,53^{\text {tn }}$ & $8,11^{\text {tn }}$ & $8,16^{\mathrm{tn}}$ & $8,18^{\mathrm{tn}}$ \\
\hline $\mathrm{P}_{4}$ & $7,77^{*}$ & $8,07 *$ & $8,17 *$ & $8,22 *$ & $7,76^{*}$ & $8,12^{\mathrm{tn}}$ & $8,20 *$ & $8,23 *$ \\
\hline $\mathrm{P}_{5}$ & 7.67 & 7.98 & 8.03 & 8.07 & 7.52 & 8.06 & 8.15 & 8.16 \\
\hline $\mathrm{D}_{0,05}$ & 0.0535 & 0.0666 & 0.025 & 0.0354 & 0.0707 & 0.1018 & 0.0263 & 0.0278 \\
\hline
\end{tabular}

*) : significant difference with control (P5), tn : unsignificant difference with control (P5) 
Relationship between cultural time (day) and soil's and water's $\mathrm{pH}$ showed that at the same dosage (6 ton/ha), mussel shell lime that was activated become $\mathrm{CaO}$ was increasing $\mathrm{pH}$ faster than calcite as common material of lime. The calcium carbonat (calcite) is a safe but slow-acting product, meanwhile the calcium oxyde fast-acting product for aquaculture liming [8]. Based on neutralizing value (NV, the relative abilities of liming materials to neutralze acidity), pure calcium carbonate is $100 \%$. Meanwhile the NV of calcium oxide relative to the calcium carbonate standard is $179 \%$ [1].

According to equations shown in Fig. 1, the maximum $\mathrm{pH}$ and days after lime application to reach maximum water $\mathrm{pH}$ can be calculated The maximum water $\mathrm{pH}$ and when it is were 7.58 at 49 days after liming, 7.95 at 48 days after liming, 8.35 at 51 days after liming, 8.32 at 53 days after liming and 8.29 at 50 days after liming, respectively for P1, P2, $\mathrm{P} 3, \mathrm{P} 4$ and $\mathrm{P} 5$. The highest maximum water $\mathrm{pH}$ among treatments was observed on P3 (6 ton/ha lime derived from mussel shells) with maximum $\mathrm{pH}$ value 8.35. This water's $\mathrm{pH}$ higher than calcite on the same dosage. Furthermore, based on the equations (Fig 1) and minimum water $\mathrm{pH}$ (6.5) for optimal growth of Pangasius sp, the next lime application should be considered after day, $109^{\text {th }}, 118^{\text {th }}, 130^{\text {th }}, 148^{\text {th }}$ and $128^{\text {th }}$ for P1, P2, P3, P4 and P5, respectively.

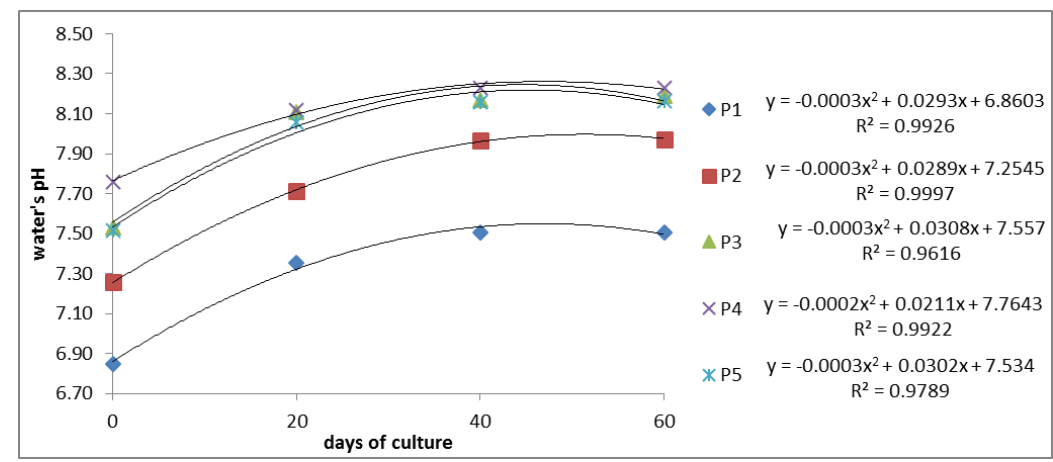

Fig. 1. Relationship between cultural time (days ) and water's $\mathrm{pH}$

Higher dosage of lime increases the water alkalinity (Fig. 2), eventhough at final day the alkalinity of ponds that using mussel shell lime showed unsignificant dfference with calcite (Table 3). Highest alkalinity was shown at P4 (liming with 7 ton/ha lime derived from mussel shells).

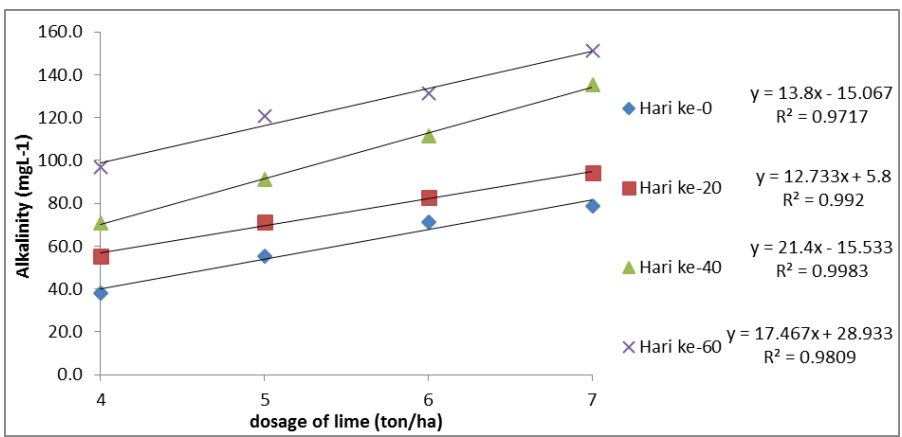

Fig 2. Relatonship between dosage of lime and alkalinity

Table 3. Dunnet test result for Alkalinity of water

\begin{tabular}{ccccc}
\hline Treatments & Day-0 & Day-20 & Day-40 & Day-60 \\
\hline P1 & $38,00^{*}$ & $55,33^{*}$ & $70,67 *$ & $96,67 *$ \\
P2 & $55,33^{*}$ & $71,33^{*}$ & $91,33^{*}$ & $142,67 *$ \\
P3 & $71,33^{\text {tn }}$ & $82,67^{\text {th }}$ & $111,33^{*}$ & $171,33^{*}$ \\
P4 & $78,67^{*}$ & $94,00^{*}$ & $135,33^{*}$ & $202,00 *$ \\
P5 & 68.67 & 79.33 & 99.33 & 157.33 \\
\hline $\mathrm{D}_{0.05} \mathrm{D}_{0.05}$ & 6.07 & 4.17 & 5.31 & 2.75
\end{tabular}

*) : significant difference with control (P5), tn : unsignificant difference with control (P5

The water temperature and dissolved oxygen (DO) of ponds (Fig 3) ranged from 27.03 to $32.17{ }^{\circ} \mathrm{C}$ and from 5.20 to $6.77 \mathrm{mg} \mathrm{L}^{-1}$, respectively. All treatment showed that the ammonia concentration increased in the final day of research (day $60^{\text {th }}$ of culture) (Fig. 4). The water temperature and dissolved oxygen of the ponds remained within the appropriate range for normal growth of juvenile 
Pangasius $s p$ [9] ranging from $27^{\circ} \mathrm{C}$ up to $30^{\circ} \mathrm{C}$ for temperature and $>5 \mathrm{mg} \mathrm{L}^{-1}$ for dissolved Oxygen. No significant effect of lime application on dissolved oxygen at the end of rearing period was detected.
Some data of temperatures exceeded the optima value, and there were some of data DO less than optimum range but still in tolerance range for Pangasius sp. culture.
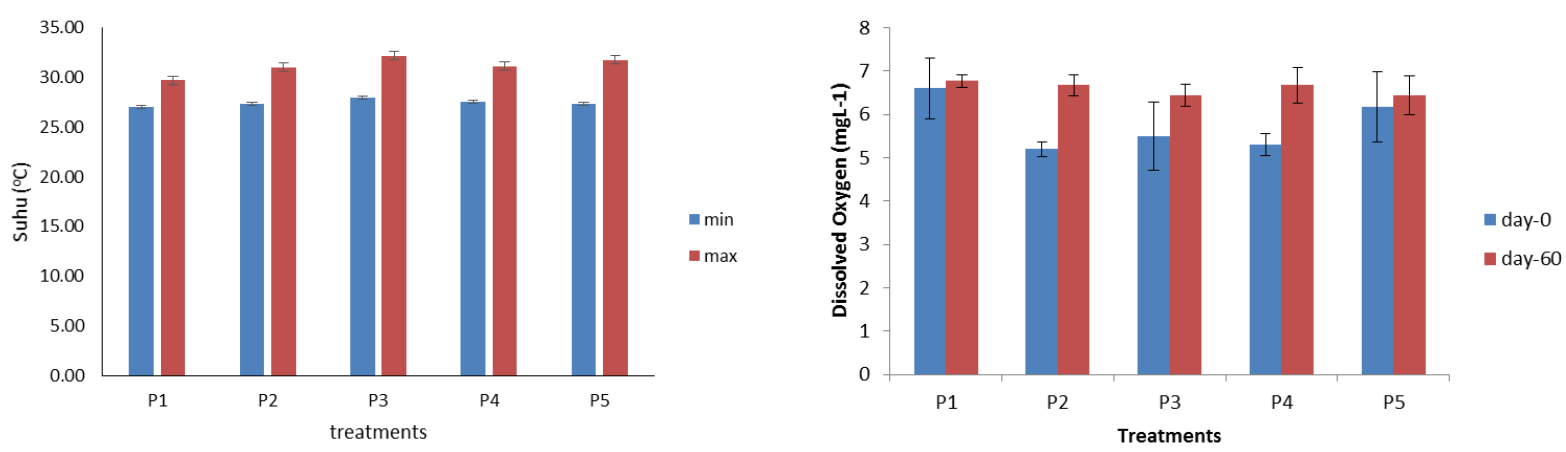

Fig. 3. Temperature (maximum and minimum) and dissolved oxygen at day-0 and day-60

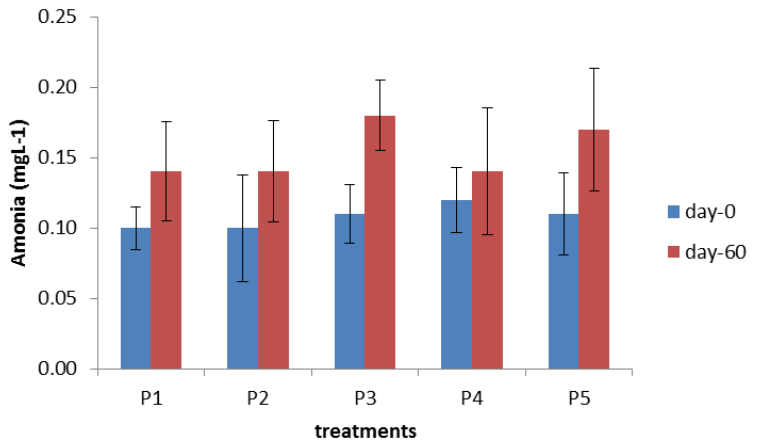

Fig. 4. Ammonia concentration in the initial (day 0 of culture) and final (day 60 of culture)

Table 4. The survival, growth and feed efficiency of catfish

\begin{tabular}{cccc}
\hline Treatments & \multicolumn{3}{c}{ Variable } \\
\cline { 2 - 4 } & Survival $(\%)$ & Absolute growth of weight $(\mathrm{g})$ & Absolute growth of length $(\mathrm{cm})$ \\
\hline P1 & 96 & 27.77 & 10.13 \\
P2 & 100 & 38.77 & 11.18 \\
P3 & 100 & 45.84 & 12.26 \\
P4 & 100 & 56.59 & 13.37 \\
P5 & 100 & 44.48 & 11.93 \\
\hline
\end{tabular}

The survival rate for all treatments was $96-100 \%$ (Table 4). The highest absolute growth and feed efficiency was achieved on P4 (lime derived from mussel shell 7 ton/ha equivalent to $\mathrm{CaO}$ (Table 4). The high survival rate indicates that the water $\mathrm{pH}$ is within the tolerant or optimal values of $\mathrm{pH}$ for Pangasius sp. Growth. Based on Dunnett test showed that lime derived form $P$. canaliculata dosage 7 ton/ha was unsignificant different with calcite dosage 6 ton/ha to survival and absoulte growth rate.

\section{Conclusion}

Liming materials freshwater mussel shells has a potency to be an altenative lime for catfish swamp ponds. In the same dosage of lime (6 ton/ha), mussel shell lime and calcite was unsignificat difference, but higher dosage of mussel shell lime (7 ton/ha) (P4) has highest soil's and water's $\mathrm{pH}(8.22$ and $8.23 \mathrm{pH}$ unit). The difference dosage of mussel shells and calcite has no significant difference for data of final day (day-60) of alkalinity, temperature, dissolved oxygen and ammonia. Survival rate and fish growth has no significant difference among treatments. 


\section{Acknowledgement}

We would like to thank Institute for Research and Community Services, Sriwijaya University that had funded this study through Hibah Kompetitif 2017.

\section{References}

[1] C.E. Boyd. Water Quality in Ponds for Aquaculture. Alabama, Birmingham Publishing Co, 1990, pp. 195-227.

[2] F.S. Zhang., S. Yamasaki and M. Nanzyo. "Waste ashes for use in agricultural production : I. Liming effect, contents of plant nutrients and chemical characteristics of some metals". The Science of the Total Environment, vol. 284, pp. 215-225, 2002

[3] D. Jubaedah, Marsi, R. R. Rizki. "Utilization of Anadara granosa as a Liming Materials for Swamp Fish Ponds for Pangasius sp Culture

[4] D. Jubaedah, M. Wijayanti, Marsi, N. Rizaldy." Utilization of Golden Apple Snail (Pomacea canaliculata) shells as Liming Materials for Pangasius sp Culture in Swamp Fish Pond, in Proc. Sricoenv, 26-27 September 2018. https://www.e3s-

conferences.org/articles/e3sconf/abs/2018/43/co ntents/contents.html\#section_10.1051/e3sconf/2 0186801001.

[5] A. Abeynaike, L. Wang, M.I. Jones and D.A. Patterson. "Pyrolysed powdered mussel shelss for eutrophication control : effect of particle size and powder concentration on the mechanism and extent of phosphate removal". Asia-Pacific Journal of Chemical engineering, vol. 6, pp. 231-243, Feb. 2011.

[6] APHA (American Public Health Association). "Standard Methods for the Examination of Water and Wastewater, 22nd Edition". Washington D.C., American Water Works, 2012, $541 \mathrm{pp}$.

[7] National Research Council (NRC)., 1977.

Nutrient Requirements of Warmwater Fishes. Washington DC: National Academy Press.

[8] M.K.B., Nobre, F.R.D.S. Lima, F.B. Magalhaes and M.V.D. E Sa. "Alternative liming blends for fish culture". Acta Scientiarum. Animal Sciences, vol 36, pp. 1-11.

[9] SNI (Standar Nasional Indonesia). Produksi benih ikan patin siam (Pangasius hypopthalmus) kelas benih sebar. Jakarta., 2000, pp, 1-11. 